\title{
Tek Basamaklı Ters Transkripsiyon Kantitatif PZR Yönteminin miRNA Ekspresyon Analizleri için Optimizasyonu
}

\author{
Optimization of One Step Reverse Transcription Quantitative PCR Method for \\ miRNA Expression Analyses
}

\author{
Seda Süsgünn ${ }^{1,2}$ (D), illker Karacan ${ }^{3}$ (D), Emrah Yücesan ${ }^{1}$ (1) \\ 'Bezmialem Vakıf Üniversitesi, Tıp Fakültesi, Tıbbi Biyoloji Anabilim Dalı, İstanbul, Türkiye \\ ${ }^{2}$ Istanbul Üniversitesi, Sağlık Bilimleri Enstitüsü, İstanbul, Türkiye \\ ${ }^{3}$ Istanbul Medeniyet Üniversitesi, Bilim ve İleri Teknoloji Uygulama ve Araştırma Merkezi, İstanbul, Türkiye
}

ORCID ID: S.S. 0000-0001-9689-3111; i.K. 0000-0003-3100-0866; E.Y. 0000-0003-4512-8764

Cite this article as: Süsgün S, Karacan I, Yücesan E. Tek basamaklı ters transkripsiyon kantitatif PZR yönteminin miRNA ekspresyon analizleri için optimizasyonu. Experimed 2021; 11(2): 113-9.

\section{öz}

Amaç: Bu çalışmada mikroRNA (miRNA) hedeflerinin spesifik olarak belirlenmesi ve ekspresyon ölçümünün yapılmasına yönelik tek basamaklı ters transkripsiyon kantitatif polimeraz zincir reaksiyonu (RT-qPZR) yönteminin, seçilen iki farklı miRNA (hsa-miR-145-5p ve hsa-miR-146a-5p) için araştırılması ve sürecin optimizasyonu amaçlanmıştır.

Gereç ve Yöntem: RNA eldesi HEK293T hücre hattından yapılmıştır. Çalışmada seçilen her iki miRNA hedefi için uygun primerler tasarlanmış, tek basamaklı RT-qPZR yöntemi ile optimizasyon işlemi gerçekleştirilmiştir. Hedef amplikonların spesifiklik doğrulamaları agaroz jel elektroforezi ve konvansiyonel dizileme yöntemi ile gerçekleştirilmiştir.

Bulgular: Tek basamakta gerçekleştirilen RT-qPZR çalışmasının her iki primer için de yüksek spesifiklikte ve hassasiyette sonuç verdiği qPZR erime eğrisi analizi ve agaroz jel görüntüleme sistemi ile gösterilmiştir. qPZR sırasındaki bağlanma sıcaklıklarından en düşük $\mathrm{Ct}$ değerinin $54^{\circ} \mathrm{C}^{\prime}$ de elde edildiği görülmüştür. Ayrıca konvansiyonel Sanger dizileme sonucunda yalnızca ilgili miRNA dizilerinin hedeflendiği ve spesifik olmayan herhangi bir çoğaltma işleminin olmadığı gösterilmiştir.

Sonuç: Sunulan çalışmada deneysel tasarım her iki miRNA hedefi için de optimize edilerek spesifik olarak yalnızca hedef miRNA molekülünün tespitinin yapılabildiği gösterilmiştir. Bu yaklaşım, ilerleyen çalışmalarda miRNA tespit ve ekspresyon analizlerinde güvenilir olarak kullanılabilecektir. Sunulan yaklaşım, düşük maliyetli, zamandan ve iş gücünden tasarruf sağlayan bir alternatif olması sebebiyle benzer tüm çalışmalarda değerlendirilebilir.

Anahtar Kelimeler: miRNA, RT-qPZR, miR-145, miR-146a

\section{ABSTRACT}

Objective: We aimed to investigate and optimize the one step reverse transcription quantitative polymerase chain reaction (RT-qP$\mathrm{CR}$ ) method for specific detection and quantitation of two selected microRNA (miRNA)s, namely hsa-miR-145-5p and hsa-miR-146a-5p.

Material and Method: RNA was extracted from HEK293T cell line. Primers were designed and experimentally optimized to be compatible with with one step RT-qPCR method for two selected miRNAs. Targeted amplicons were visualized with agarose gel electrophoresis and sequenced using the Sanger method for specificity verification.

Results: High specificity of one step RT-qPCR amplification was demonstrated using melt curve and agarose gel electrophoresis analyses for both miRNA targets. It was shown that the earliest cycle threshold $(\mathrm{Ct})$ values were obtained at the annealing temperature of $54^{\circ} \mathrm{C}$. Also, target specificity was confirmed by conventional Sanger sequencing.

Conclusion: In this study, one-step RT-qPCR design was optimized for both miRNA targets and target specificity was verified. Our study showed this approach to be a good candidate for miRNA detection and quantitation as a cost-effective alternative method. Furthermore, the approach is highly suitable for research projects as it is both low-cost and fast, involving less hands-on time.

Keywords: miRNA, RT-qPCR, miR-145, miR-146a 


\section{GíRiş}

MikroRNA'lar (miRNA) ilk olarak 1993 yılında Caenorhabditis elegans'da keşfedilmiş (1) ve ardından hız kazanan çalışmalar sonucunda miRNA'ların neredeyse tüm ökaryotik hücrelerde bulunduğu belirlenmiştir (2). miRNA'lar evrimsel olarak korunmuş genetik diziler olup, protein kodlamayan RNA'lardır (3). Öncül miRNA'lar nükleer ve sitoplazmik işlemlerden DROSHA ve DICER endoribonükleazları aracılığıyla geçer ve nihayetinde olgunlaşan miRNA'lar RNA kaynaklı susturma kompleksi (RNA-induced silencing complex, RISC)'e dahil olurlar. Bu kompleks içerisinde miRNA'lar hedeflerine eşlenerek bağlanır ve biyolojik fonksiyonunu gerçekleştirir (4). miRNA'lar, RNA susturma mekanizmasında rehber molekül olarak bulunur ve genellikle protein kodlayan transkriptleri hedefleyerek (mRNA), neredeyse tüm gelişimsel ve patolojik mekanizmalarda post-transkripsiyonel düzenleyici olarak görev alır (3). miRBase veri tabanının son güncellemesiyle (v22.1) birlikte 271 organizmada 48.885 olgun miRNA tanımlanmıştır, insanlarda ise 1.917 öncül ve 2.654 olgun miRNA bilgisi bulunmaktadır $(5,6)$.

Klinik örneklerden alınan parafine gömülü dokularda ve plazmada miRNA'ların yüksek stabilite gösterdiği ve ifade düzeyinde değişiklikler olduğuna dair bulgular miRNA'ları hastalıkların tanısında umut verici biyobelirteç adayları yapmıştır (7). Bugüne kadar miRNA'ların ifade düzeyindeki değişimler kanser, diyabet, immün sistem hastalıkları, kas hastalıkları ve nörodejenerasyon gibi birçok hastalık ile ilişkilendirilmiştir (8).

miRNA tespiti ve ekspresyon analizi için çok sayıda yöntem geliştirilmiştir ancak her yöntemin sınırılıkları bulunmaktadır (9). Northern blot ve microarray analizleri konvansiyonel olmakla birlikte miRNA konsantrasyonlarının yetersiz olduğu durumlarda istenen hassasiyeti gösterememektedir (7). Hassasiyeti ve spesifikliği arttırmak adına nanopartikül amplifikasyon metodu, konjuge-polimer bazlı yöntem, ters transkripsiyon polimeraz zincir reaksiyonu (Reverse Transcription Polymerase Chain Reaction, RT-PZR), ribozim amplifikasyon yöntemi, izotermal amplifikasyon, elektrokimyasal metot gibi çok sayıda yöntem geliştirilmiştir (10). Bu metodlar arasında RT-PZR yöntemi en pratik olanıdır ancak miRNA'lar için zaman alıcı bir ters transkripsiyon adımını içermeleri ve kullanılan bazı probların maliyetleri nedeniyle yine de tam olarak istenen özellikleri taşımamaktadır. Bu dezavantajları ortadan kaldırmak amacıyla Yan ve ark. tarafından "Tek basamaklı gerçek zamanlı ters transkripsiyon PZR" (RTqPZR) yöntemi geliştirilmiştir. Geliştirilen bu sistemde tek bir tüp içerisinde tüm bileşenler bulunmakta ve reaksiyonlar bir gerçek zamanlı PZR cihazında ardışık olarak yürütülmektedir (8).

Sunulan çalışmamızda tek basamaklı RT-qPZR yöntemi ele alınmıştır. Deney ve primer tasarımları tarafımızca yapılarak gelecek miRNA çalışmalarında kullanılmak üzere kendi laboratuvar sistemimizde optimize edilmeye çalışılmıştır. Bu amaçla; RNA kaynağı olarak HEK293T hücre hattı kullanılmıştır ve iki farklı miRNA (miR-145-5p ve miR-146a-5p) için tek tüp içerisinde ardışık ters transkripsiyon ve PZR basamakları optimize edilmiştir. Bu çalışmadan elde edilen sonuçlara göre, deneysel olarak kalitatif ve kantitatif doğrulaması da yapılan bu yaklaşımın, diğer hedef miRNA'lar için de uyarlanabilmesi olanaklıdır ve bu sayede hızlı, kolay ve düşük maliyetli olarak miRNA tespiti ve ekspresyon ölçümünün gerçekleştirilmesi mümkün olacaktır.

\section{GEREÇ VE YÖNTEM}

\section{RNA İzolasyonu}

Çalışmamızda HEK293T (Human Embryonic Kidney 293T) hücre hattı kullanılmıştır. RNA izolasyonları Qiagen RNeasy Tissue Mini Kit (QIAGEN, Hilden, Almanya) kullanılarak üreticinin protokolüne uygun olarak gerçekleştirilmiştir. RNA konsantrasyonları ve saflıkları Multiskan GO (Thermo Fisher Scientific, Massachusetts, $A B D$ ) cihazı ile değerlendirilmiştir. RNA için ölçülen $A_{260 / 280}$ oranı $\sim 2,0$ ve $A_{260 / 230}$ oranı $\sim 2,0-2,2$ olması durumunda örnekler $50 \mathrm{ng} / \mu \mathrm{l}$ konsantrasyonda olacak şekilde seyreltilerek $-80^{\circ} \mathrm{C}^{\prime}$ de saklanmıştır.

\section{Primer Dizaynı}

Tek basamaklı RT-qPZR primerleri Yan ve ark. (8) tarafından geliştirilen yöntem temel alınarak tasarlanmıştır. Bu amaçla öncelikle çalışılacak miRNA'lara ait dizi bilgileri (hsa-miR-1455p \#MIMAT0000437 ve hsa-miR-146a-5p \#MIMAT0000449) miRBase veri tabanından alınmıştır (5). Tek basamaklı RT-qPZR yönteminde iki çift olmak üzere toplamda dört primer gerekmektedir (Şekil 1). Buna göre ilk çift primer (RP1 ve RP2) miRNA spesifiktir, her miRNA için özel olarak tasarlanmıştır. RP1 primeri; P1 primerinin dizisini ve R1 olarak belirtilen hedef miRNA'nın 3'ucuna komplementer dizi içerir. RP2 ise P2 primerinin dizisini ve R2 olarak adlandırılan hedef miRNA'nın 5'ucuna komplementer dizi içerir. RP1 ve RP2 primerleri ters transkripsiyon işlemi için kullanılmıştır. İkinci çift P1 ve P2 primerleri ise sabit dizili primerlerdir, qPZR işlemi için gereklidir ve literatürde daha önce bildirilen primer dizileri kullanılmıştır (11). Tüm primer tasarımları sRNAPrimerDB online biyoinformatik aracı kullanılarak yapılmıştır (11). miRNA spesifik RP1, RP2 primerleri ile evrensel $\mathrm{P} 1$ ve $\mathrm{P} 2$ primerlerinin dizileri Tablo 1'de verilmiştir.

Tek Basamaklı RT-qPZR Yönteminin Uygulanması ve Ürünlerin Konfirmasyonu

Tek basamaklı RT-qPZR yönteminde hazırlanan reaksiyonlar Tablo 2'de, uygulanan koşullar Tablo 3'te sunulmuştur. Tek basamaklı RT-qPZR yöntemi temelde iki aşamadan oluşmaktadır; ters transkripsiyon ve PZR. Kullanılan PZR master karışımı $25 \mu l^{\prime}$ lik reaksiyonda $100 \mathrm{U}$ PrimeScript Reverse Transcriptase (Takara Bio, ABD) 1,25 U TaKaRa Taq HS (Takara Bio, ABD), RNaz inhibitörü, dNTP ve bu enzimlerin tampon çözeltisini içerecek şekilde hazırlanmıştır.

Birinci aşamada ters transkripsiyon reaksiyonu $52^{\circ} \mathrm{C}$ 'de 5 dakika ve $95^{\circ} \mathrm{C}$ 'de 10 saniye olacak şekilde gerçekleştirilmiştir. Bu aşamada; RP1 primerinin R1 dizisi hedef miRNA'nın 3'ucuna bağlanır, ters transkriptaz enzimi ve dNTP'ler varlığında uzama reaksiyonu gerçekleşir. Aynı zamanda oluşan bu çift zincirli yapılara RP2 primerinin komplementer R2 dizisi bağlanır ve ortamda bulunan Hot-Start Taq polimeraz (HS-Taq) enzimi sayesinde uzama gerçekleşir. Ardından $95^{\circ} \mathrm{C}$ 'de reaksiyondaki ters transkriptaz enzimi inhibe edilir ve qPZR aşamasına geçilir. 


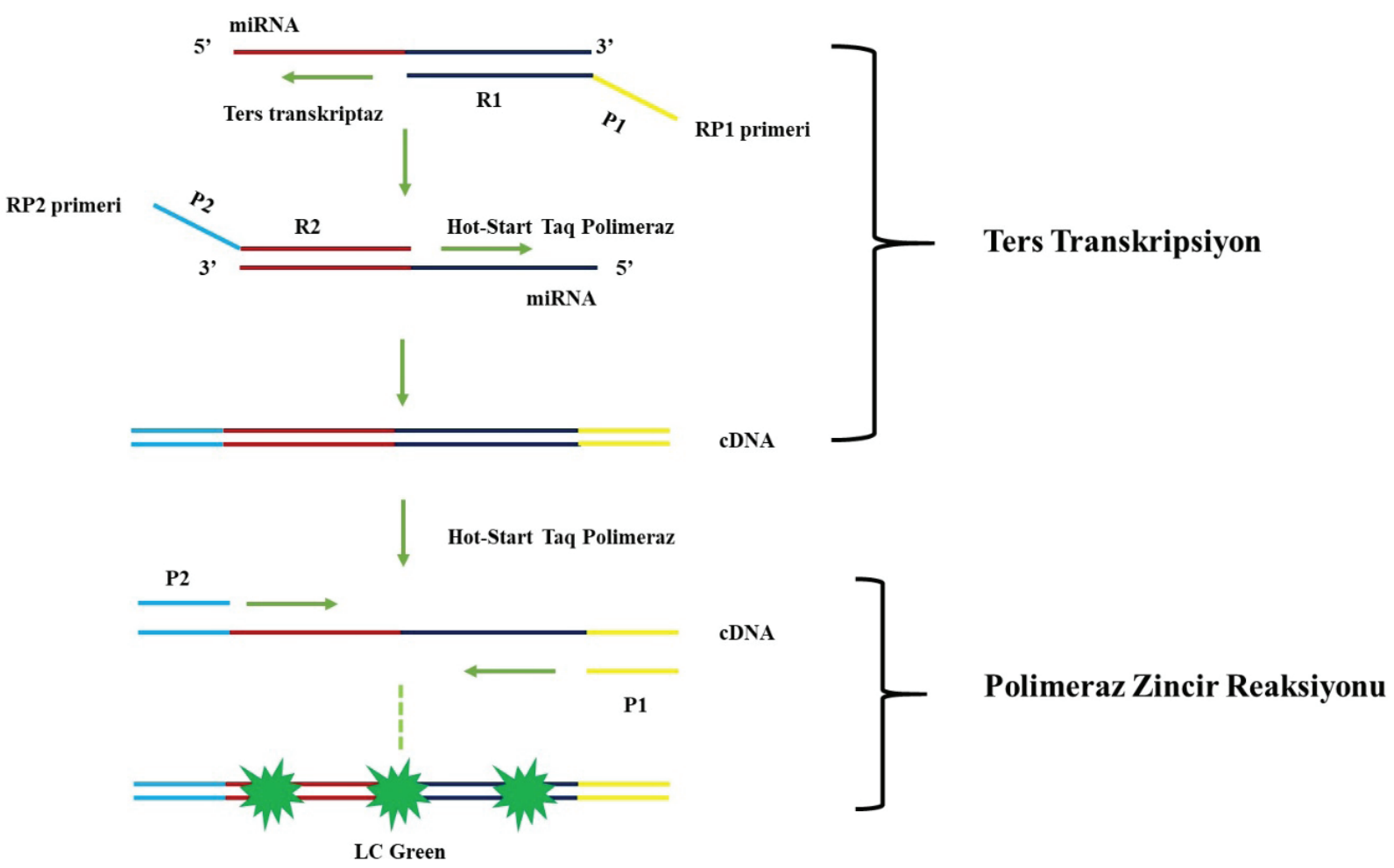

Şekil 1. Tek basamaklı RT-qPZR yönteminin çalışma prensibi.

Tablo 1. Tek basamaklı RT-qPZR yönteminde kullanılan primer dizileri.

\begin{tabular}{ll}
\hline Primer & $\mathbf{5}$ '-3' primer dizisi \\
\hline hsa-miR-145-5p RP1 & GGACGGTAGCAAGCAAAGAGTGTGAGGGATTCCTG \\
\hline hsa-miR-145-5p RP2 & GGGATTCTGGAAGATGATGATGACGTCCAGTTTTC \\
\hline hsa-miR-146a-5p RP1 & GGACGGTAGCAAGCAAAGAGTGTGAACCCATGGAA \\
\hline hsa-miR-146a-5p RP2 & GGGATTCTGGAAGATGATGATGACTGAGAACTGAA \\
\hline P1 & GGACGGTAGCAAGCAAAGAGTGTG (11) \\
\hline P2 & GGGATTCTGGAAGATGATGATGAC (11) \\
\hline
\end{tabular}

İkinci aşama konvansiyonel PZR yöntemidir. Ters transkripsiyon aşamasından gelen çift zincirli yapılara eklenen evrensel diziler sayesinde $\mathrm{P} 1$ ve $\mathrm{P} 2$ primerleri kullanılarak, HS-Taq polimeraz ve dNTP'lerin varlığında $95^{\circ} \mathrm{C}$ 'de 10 saniye ve erime sıcaklığında (gradiyent oluşturularak çalışılmıştır) 30 saniye olacak şekilde 40 döngüde PZR gerçekleştirilmiştir. Bu PZR karışımına ek olarak floresan bir DNA boyası olan LC Green eklenmiştir, bu sayede cDNA amplifikasyonu gerçek zamanlı olarak izlenmiş ve erime eğrisi analizi yapılmıştır.

PZR döngüsünün bitmesini takiben yapılan erime eğrisi analizi sayesinde hedeflenmeyen amplifikasyon ürünlerinin varlığı araştırılmıştır. Erime eğrisi analizi; $65^{\circ} \mathrm{C}$ 'den $95^{\circ} \mathrm{C}^{\prime}$ ye yavaş ısıtmayla elde edilmiş ve her $0,5^{\circ} \mathrm{C}$ sıcaklık artışında floresan ölçümleri alınmıştır. RT-qPZR çalışmaları Bio-Rad CFX96 Connect
(Bio-Rad Laboratories, Inc., California, ABD) Isı döngü cihazında yapılmıştır. Ek olarak, RT-qPZR sonrasında elde edilen ürünler $\% 2$ 'lik agaroz jel yardımıyla incelenmiş ve amplifiye edilen örneklerin uzunlukları kontrol edilmiştir. İleri konfirmasyon amacıyla hsa-miR-145-5p'ye ait tek örnekte konvansiyonel Sanger dizileme işlemi yapılmıştır (Macrogen Inc., Seul, Güney Kore).

\section{BULGULAR}

Çalışma kapsamında ilk olarak her iki miRNA için de tek basamaklı gradiyent gerçek zamanlı RT-PZR yapılarak primerlerin bağlanma sıcaklıkları belirlenmiş ve erime eğrisi analizi yapılmıştır. Şekil $2^{\prime}$ de dört farklı sıcaklık için $\left(58,6^{\circ} \mathrm{C} / 57,6^{\circ} \mathrm{C} / 56^{\circ}\right.$ $\mathrm{C} / 54^{\circ} \mathrm{C}$ ) elde edilen $\mathrm{Ct}$ (Cycle threshold) değerleri ve erime eğrileri verilmiştir. Buna göre primerlerin optimum bağlanma 
Tablo 2. Tek basamaklı RT-qPZR için hazırlanan reaksiyon bileşenleri ve miktarları.

\begin{tabular}{lc}
\hline Reaktifler & $\mathbf{1 X}(\boldsymbol{\mu l})$ \\
\hline PZR master karışımı $(2 \mathrm{X})$ & 10 \\
\hline P1 evrensel primer $(2,5 \mu \mathrm{M})$ & 1,6 \\
\hline P2 evrensel primer $(2,5 \mu \mathrm{M})$ & 1,6 \\
\hline miRNA spesifik RP1 primeri $(2,5 \mu \mathrm{M})$ & 0,4 \\
\hline miRNA spesifik RP2 primeri $(2,5 \mu \mathrm{M})$ & 0,4 \\
\hline Kalıp RNA $(50 \mathrm{ng} / \mu \mathrm{l})$ & 1,5 \\
\hline LC Green $(10 \mathrm{X})$ & 2 \\
\hline $\mathrm{dH}{ }_{2} \mathrm{O}$ & 2,5 \\
\hline Toplam & $20 \mu \mathrm{l}$ \\
\hline
\end{tabular}

Tablo 3. Tek basamaklı RT-qPZR koşulları.

\begin{tabular}{|c|c|c|c|}
\hline Sıcaklık & Süre & Döngü Sayısı & Yöntem \\
\hline $52^{\circ} \mathrm{C}$ & $5 \mathrm{dk}$ & \multirow[b]{2}{*}{1} & \multirow[b]{2}{*}{ Ters transkripsiyon } \\
\hline $95^{\circ} \mathrm{C}$ & $10 \mathrm{sn}$ & & \\
\hline $95^{\circ} \mathrm{C}$ & $5 \mathrm{sn}$ & \multirow{2}{*}{40} & \multirow{2}{*}{$\begin{array}{l}\text { Polimeraz zincir } \\
\text { reaksiyonu }\end{array}$} \\
\hline $54^{\circ} \mathrm{C}$ & $30 \mathrm{sn}$ & & \\
\hline $65^{\circ} \mathrm{C}-95^{\circ} \mathrm{C}$ & $0,5^{\circ} \mathrm{C} / \mathrm{sn}$ & 1 & Erime eğrisi analizi \\
\hline
\end{tabular}

sıcaklığı en düşük Ct değerinin alındığı ve hedef dışı amplifikasyon görülmeyen $54^{\circ} \mathrm{C}$ olarak belirlenmiştir. Erime eğrileri dikkate alındığında tek bir noktada erime piki alındığı görünmektedir dolayısıyla hedef dışı PZR ürününün olmadığı yorumu yapılabilmektedir.

Ardından elde edilen ürünler \%2'lik agaroz jel yardımıyla görüntülenmiştir (Şekil 3). Son olarak, ileri konfirmasyon amacıyla hsa-miR-145-5p için tek basamaklı RT-qPZR ürünü Sanger dizilemeye tabi tutulmuştur. Sanger dizileme sonuçları CLC Main Workbench v5.0.2 (QIAGEN, Hilden, Almanya) programı kullanılarak analiz edilmiştir. Şekil 4'te gösterildiği haliyle verilen dizi sonuçlarına göre amplifiye edilen ürün dizisi miRBase veri tabanından alınan hsa-miR-145-5p dizisi ile aynıdır.

\section{TARTIŞMA}

miRNA'lar neredeyse tüm ökaryotik hücrelerde bulunan kodlamayan RNA molekülleridir ve miRBase veri tabanının son sürümüne göre (v22.1) insanlarda öncül miRNA sayısı 1.917 olarak belirtilmiştir ancak yapılan deneysel konfirmasyon çalışmaları ile bu sayının çok daha yüksek olabileceği öngörülmüştür (6).

Klinik örneklerde miRNA'ların yüksek stabilizasyon göstermesi ve bu sayede biyobelirteç olma potansiyelleri miRNA ekspresyon çalışmalarına ivme kazandırmıştır. Bu anlamda yapılan kilit çalışmalardan biri 2005 yılında Nature dergisinde yayımlanmıştır. Buna göre, 217 memeli miRNA'sı ele alınmış ve tümör dokusu, sağlıkı doku, kanser hücre hatları, klinik örnekler, fare tümörleri dahil 334 farklı örnekte yapılan incelemeler sonucunda miRNA'ların büyük kısmının enformatif olduğu ve hatta tümörün gelişimsel aşamasını dahi güvenilir bir şekilde yansıttığı belirlenmiştir (12).
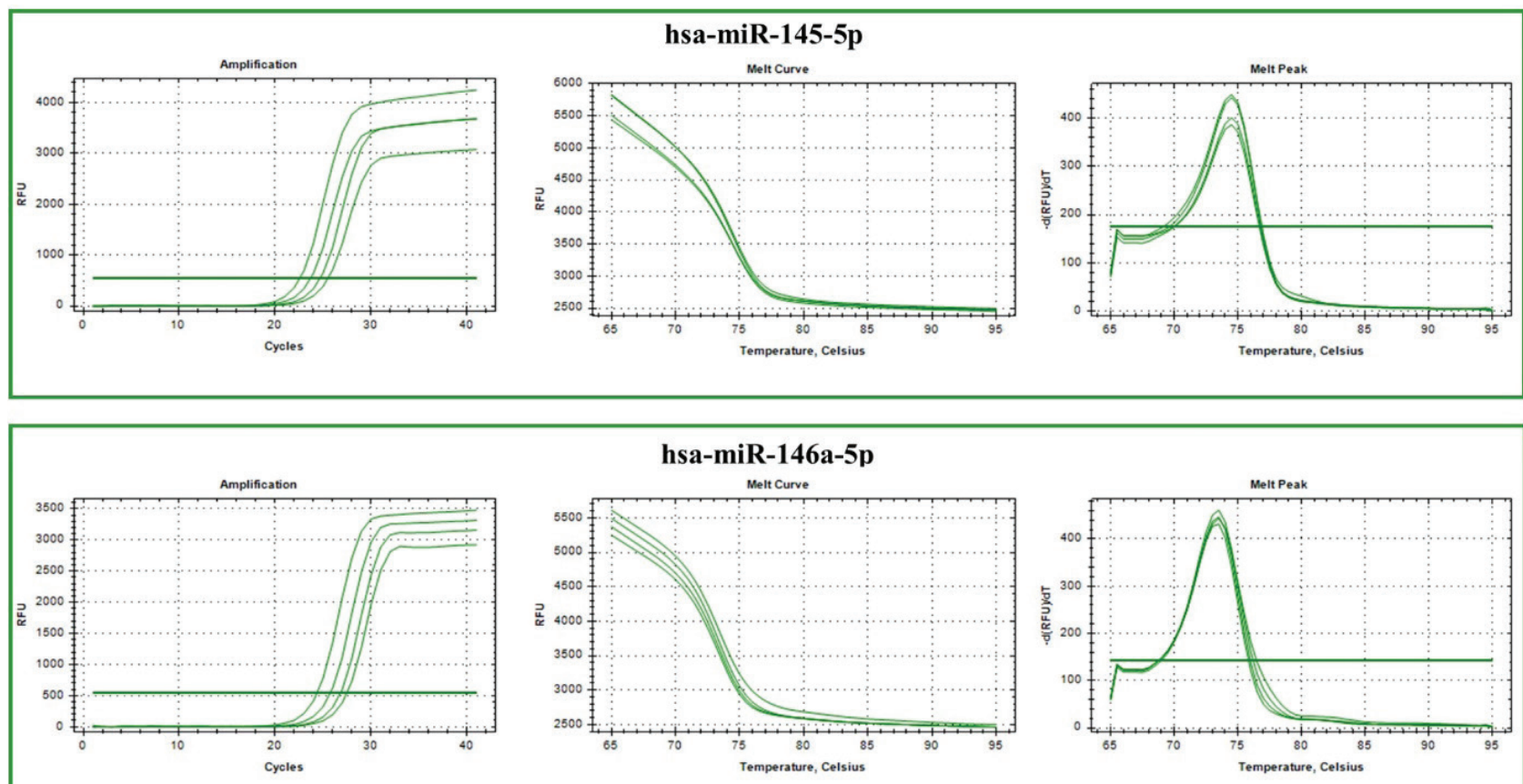

Şekil 2. Tek basamaklı gradiyent RT-PZR sonuçları. 


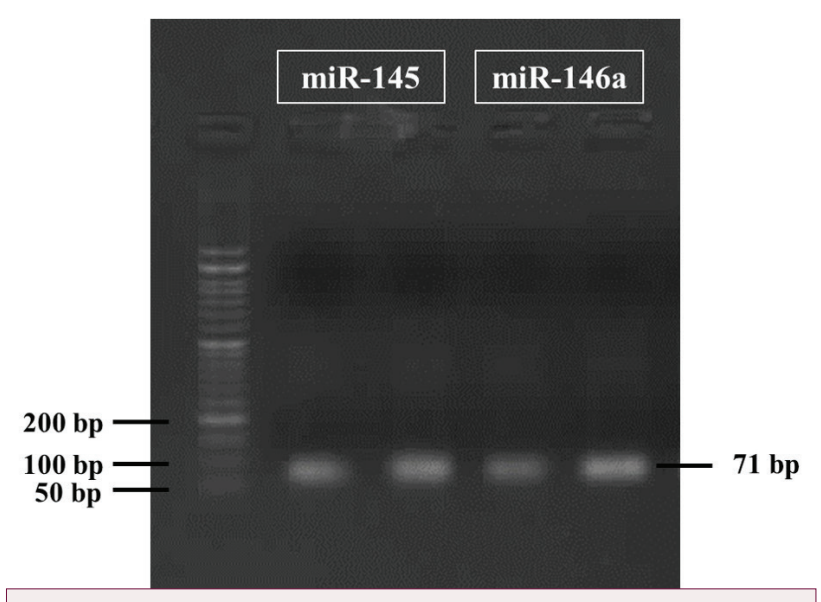

Şekil 3. Tek basamaklı RT-PZR ürünlerinin agaroz jel görüntüleri.

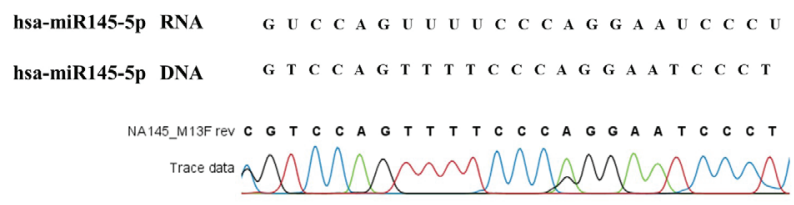

Şekil 4. hsa-miR-145-5p PZR ürününün Sanger dizileme kromatogramı.

Bugüne kadar yapılan çok sayıda çalışma bu verileri doğrular niteliktedir. İnsan miRNA-ilişkili hastalık veri tabanının (The human miRNA-associated disease database-HMDD) son sürümünde (v3.2) 1.206 miRNA'nın 893 hastalıkla ilişkilendirildiği 19.280 yayın bulunmaktadır. Bu bilgiler ışığında miRNA'ların çeşitli kritik biyolojik süreçlerde önemli roller oynadığını söylemek mümkündür (13).

miRNA'ların saptanması ve kantitasyonu için çok sayıda yöntem geliştirilmiştir ancak optimum bir yöntem henüz belirlenememiştir ve her yöntemin kendine özgü avantajları ile dezavantajları bulunmaktadır. Bunlar arasında; mikroarray çalışmaları yüksek çıtılı miRNA ifade çalışmalarına imkân tanısa da duyarlılık ve özgüllük açısından nispeten sınırlıdır (14). Northern blot yöntemi görece karmaşıktır ve sinyal artefaktları önemli bir sorun teşkil etmektedir (10). Aynı zamanda hibridizasyon temelli çalışmalarda hem öncül hem de olgun miRNA'lara probların bağlanma ve yanlış pozitiflik verme ihtimali vardır (7). miRNA dizileme çalışmaları yüksek çıktılı olmasına rağmen veri analizi için yüksek altyapı ve ekipman ile tecrübeli araştırmacı gerektirmektedir ve oldukça maliyetli bir yöntemdir (15). Tüm sınırlayıcı parametreler göz önünde bulundurularak düşük maliyetli ve yüksek verimli olabilecek; nanopartikül-aracılı problar, izotermal amplifikasyon, elektrokimyasal metot gibi çok sayıda yöntemin uygulanması mümkündür (10). Geliştirilen bu yöntemlerden özellikle ddPZR (droplet digital PCR) platformları olumlu sonuçları ile umut vaat etmektedir. Bu yöntemde pozitif ve negatif damlacıklardan gelen floresan sinyaller kullanılarak absolüt kantitasyon yapılır. ddPZR'de referans gene ihtiyaç duyulmaz, düşük miktarda örnekten yüksek hassasiyete sahip sonuçlar alınabilir. ddPZR yöntemi RT-qPZR yöntemleri ile karşılaştırıldığında dolaşımdaki miRNA'ların analizinde hem teknik performans hem de tanı potansiyeli açısından üstünlük göstermiştir (16). Fakat bu yöntemde de kullanılması gereken cihazlar uygulamaya özgü olup, qPZR cihazları gibi yaygın olarak laboratuvarlarda bulunmamaktadır. Cihaz ve sarf maliyetleri düşünüldüğünde kullanım alanı geniş olabilecek olsa dahi, maliyet açısından etkin bir yöntem değildir.

Tüm bunların yanında gerçek zamanlı PZR yöntemi gen ekspresyonunun kantitasyonunda maliyet ve kolay uygulanabilirlik açısından hala altın standart olarak kabul edilmektedir (14). miRNA çalışmalarında PZR temelli evrensel veya spesifik primerlerle ters transkripsiyon yaklaşımı bulunmaktadır $(17,18)$. Evrensel ters transkripsiyon yaklaşımında, tüm miRNA moleküllerine cDNA dönüşümü için bilinen tek özdeş bir kuyruk eklenmektedir. Bu kuyruk; 3' ucuna poly-A polimeraz ile poly-A kuyruğunun eklenmesi (15), poly-U polimeraz yardımı ile poliuridilasyon (19), T4 RNA ligaz ile evrensel linkerların eklenmesi (20) veya hem linker hem de kuyruk eklenmesi kombinasyonu şeklinde uygulanabilmektedir. Bu yaklaşımların temel avantajı, tüm miRNA'ların aynı tüpte cDNA'ya dönüşümüne olanak sağlamasıdır ancak arka plan kirliliği bu yaklaşımın sınırlayıcı parametresidir (21).

İkinci grupta ise spesifik lineer primerler, kıskaç probları (pincer probes) ve Stem-loop RT primerleri kullanılır. Stem-loop metodu günümüzde en sık kullanılan yöntemlerdendir (22-24). Geleneksel Stem-loop yönteminde her miRNA için yeni bir spesifik Stem-loop primeri tasarlanmalıdır, bu primer olgun miRNA'ların 3' ucuna bağlanır ve ardından cDNA sentezlenir. Buna ek olarak evrensel Stem-loop primer kullanımı da geliştirilmektedir $(14,15)$.

Tek basamaklı RT-qPZR yöntemi ise miRNA çalışmalarında hassas ve spesifik kantitasyon sağlamaktadır. Bu yöntemde, tek tüp içerisinde ters transkripsiyon ve PZR aşamaları ardışık olarak, gerçek zamanlı PZR cihazında tek seferde yürütülür. Sistemin en büyük avantajı ayrı bir ters transkripsiyon aşamasına ihtiyaç duymaması ve çok kısa sürede sonuca ulaşmayı sağlamasıdır. Uygulama kolaylığının yanı sıra bu yöntem aynı zamanda iki basamaklı PZR temelli miRNA kantitasyon yöntemlerine göre kontaminasyon riskini azaltmakta ve bu sayede yüksek numune sayılı çalışmalar için daha verimli olmaktadır (8). Bununla birlikte, birçok avantajının yanı sıra yöntemin tek basamaklı olması beraberinde bazı sınırlamalar da doğurmaktadır; ters transkripsiyon ve PZR basamakları aynı tüpte gerçekleştirildiği için ayrı ayrı optimize edilememektedir, bu durum ise her iki basamakta daha düşük verime yol açabilmektedir. Ek olarak, sentezlenen cDNA'ların tamamı hemen sonrasında PZR yönteminde kullanılmaktadır, bu nedenle herhangi bir sulandırma işlemi gerçekleştirilememektedir. Bir diğer kısıtlama ise sonuçlar açısından olumsuz bir durum sergilemese de başlangıç materyalinin daha stabil olan cDNA yerine kırılgan RNA olmasıdır. Tüm bu bilgiler göz önünde bulundurularak her çalışma için o deneye uygun yöntem tercih edilmelidir. Tek seferde ve RNA'dan gerçekleştirilen işlemler hem araştırma hem de tanı 
laboratuvarı pratiğinde aktif olarak kullanılmaktadır. Örnek vermek gerekirse; bu yöntem günümüzde hızı ve uygulama kolaylığı nedeniyle COVID-19'un etiyolojik tespiti için kullanılmakta ve altın standart olarak kabul edilmektedir. Vakalardan alınan sürüntülerden izole edilen SARS-CoV-2 RNA genomu tek tüp içerisinde önce ters transkripsiyon sonra da PZR işlemine tabi tutularak hızlı bir şekilde analiz edilmektedir $(25,26)$.

Sunulan çalışmada tek basamaklı RT-qPZR yönteminin seçilen hedef miRNA'lar için optimizasyonu denenmiştir. Çalışmamızın kısıtııı̆̆ı; az sayıda örnek kullanılması ve sınırlı sayıda miRNA için optimizasyonun gerçekleştirilmiş olmasıdır. Sunulan çalışmada deneysel optimizasyon için hsa-miR-145-5p ve hsa-miR146a-5p miRNA hedefleri seçilmiştir. Bu hedef miRNA'lar için alınan sonuçlar güvenilir şekilde deneysel olarak doğrulanmış olsa da bu dizaynın diğer hedef miRNA'lar için benzer hassasiyetlere sahip olma durumları ayrıca incelenmelidir. Bu sebeple her çalışılacak miRNA hedefi için deneysel optimizasyon ve doğrulamalara intiyaç duyulabilecektir.

Sonuç olarak, önerilen yaklaşım ile tek basamaklı RT-qPZR yaklaşımı ile miRNA tespiti ve ekspresyon ölçülmesi mümkün hale gelmiştir. Bu yaklaşım ile yapılan dizayn hsa-miR-145-5p ve hsamiR-146a-5p miRNA hedef dizileri için denenmiş ve en az optimizasyon ihtiyacı ile hassas sonuçlar alınabildiği görülmüştür. Bu sayede yüksek maliyetli miRNA tespit ve ölçümü yapan ticari kitlere olan bağımlılık azaltılabilecektir.

Etik Komite Onayı: Bu çalışmada, etik komite iznine gerek duyulacak bir materyal ya da deney hayvanı kullanılmamıştır.

\section{Hakem Değerlendirmesi: Dış bağımsız.}

Yazar Katkıları: Çalışma Konsepti - S.S., I.K, E.Y.; Literatür Tarama - S.S., I.K.; Deneysel Analiz - S.S., I.K., E.Y.; Veri Analizi/Yorumlama - S.S., I.K., E.Y.; Yazım: S.S., İ.K., E.Y.; İçeriğin Eleştirel İncelemesi - S.S., I.K., E.Y.; Son Onay ve Sorumluluk - S.S., I.K., E.Y.

Çıkar Çatışması: Yazarlar çıkar çatışması olmadığını bildirmişlerdir.

Finansal Destek: Bu çalışma Bezmialem Vakıf Üniversitesi Bilimsel Araştırma Projeleri Birimi tarafından desteklenmiştir (Proje no: 20200906).

Ethics Committee Approval: Ethics committee approval is not required because of no material or experimental animal that would require permission.

Peer-review: Externally peer-reviewed.

Author Contributions: Conception/Design of Study - S.S., I.K., E.Y.; Literature Reading - S.S., I.K.; Experimental Analysis - S.S., I.K., E.Y.; Data Analysis/Interpretation - S.S., I.K., E.Y.; Drafting - S.S., I..K., E.Y.; Critical Revision of Manuscript - S.S., I.K., E.Y.; Final Approval and Accountability - S.S., I.K., E.Y.

Conflict of Interest: The authors have no conflict of interest to declare.

Financial Disclosure: This study was supported by Bezmialem Vakif University Scientific Research Projects (Project no: 20200906).

\section{KAYNAKLAR/REFERENCES}

1. Lee RC, Feinbaum RL, Ambros V. The C. elegans heterochronic gene lin-4 encodes small RNAs with antisense complementarity to lin-14. Cell. 1993; 75(5): 843-54. [CrossRef]

2. Vishnoi A, Rani S. MiRNA Biogenesis and Regulation of Diseases: An Overview. Methods Mol Biol. 2017; 1509: 1-10. [CrossRef]

3. Ha M, Kim VN. Regulation of microRNA biogenesis. Nat Rev Mol Cell Biol. 2014; 15(8): 509-24. [CrossRef]

4. Michlewski G, Caceres JF. Post-transcriptional control of miRNA biogenesis. RNA. 2019; 25(1): 1-16. [CrossRef]

5. Kozomara A, Birgaoanu M, Griffiths-Jones S. miRBase: from microRNA sequences to function. Nucleic Acids Res. 2019; 47(D1): D155-D62. [CrossRef]

6. Alles J, Fehlmann T, Fischer U, Backes C, Galata V, Minet M, et al. An estimate of the total number of true human miRNAs. Nucleic Acids Res. 2019; 47(7): 3353-64. [CrossRef]

7. Hydbring $P$, Badalian-Very G. Clinical applications of microRNAs. F1000Res. 2013; 2: 136. [CrossRef]

8. Yan J, Zhang N, Qi C, Liu X, Shangguan D. One-step real time RT-PCR for detection of microRNAs. Talanta. 2013; 110: 190-5. [CrossRef]

9. Androvic P, Valihrach L, Elling J, Sjoback R, Kubista M. Two-tailed RT-qPCR: a novel method for highly accurate miRNA quantification. Nucleic Acids Res. 2017; 45(15): e144. [CrossRef]

10. Tian T, Wang J, Zhou X. A review: microRNA detection methods. Org Biomol Chem. 2015; 13(8): 2226-38. [CrossRef]

11. Xie S, Zhu Q, Qu W, Xu Z, Liu X, Li X, et al. sRNAPrimerDB: comprehensive primer design and search web service for small non-coding RNAs. Bioinformatics. 2019; 35(9): 1566-72. [CrossRef]

12. Lu J, Getz G, Miska EA, Alvarez-Saavedra E, Lamb J, Peck D, et al. MicroRNA expression profiles classify human cancers. Nature. 2005 ;435(7043): 834-8. [CrossRef]

13. Huang Z, Shi J, Gao Y, Cui C, Zhang S, Li J, et al. HMDD v3.0: a database for experimentally supported human microRNA-disease associations. Nucleic Acids Res. 2019; 47(D1): D1013-D7. [CrossRef]

14. Chen C, Ridzon DA, Broomer AJ, Zhou Z, Lee DH, Nguyen JT, et al. Real-time quantification of microRNAs by stem-loop RT-PCR. Nucleic Acids Res. 2005; 33(20): e179. [CrossRef]

15. Saliminejad K, Khorram Khorshid HR, Soleymani Fard S, Ghaffari SH. An overview of microRNAs: Biology, functions, therapeutics, and analysis methods. J Cell Physiol. 2019; 234(5): 5451-65. [CrossRef]

16. Robinson S, Follo M, Haenel D, Mauler M, Stallmann D, Tewari M, et al. Droplet digital PCR as a novel detection method for quantifying microRNAs in acute myocardial infarction. Int J Cardiol. 2018; 257: 247-54. [CrossRef]

17. Li J, Yao B, Huang H, Wang Z, Sun C, Fan Y, et al. Real-time polymerase chain reaction microRNA detection based on enzymatic stem-loop probes ligation. Anal Chem. 2009; 81(13): 5446-51. [CrossRef]

18. Jin J, Vaud S, Zhelkovsky AM, Posfai J, McReynolds LA. Sensitive and specific miRNA detection method using SplintR Ligase. Nucleic Acids Res. 2016; 44(13): e116. [CrossRef]

19. Mei Q, Li X, Meng Y, Wu Z, Guo M, Zhao Y, et al. A facile and specific assay for quantifying microRNA by an optimized RT-qPCR approach. PLoS One. 2012; 7(10): e46890. [CrossRef]

20. Benes V, Collier P, Kordes C, Stolte J, Rausch T, Muckentaler MU, et al. Identification of cytokine-induced modulation of microRNA expression and secretion as measured by a novel microRNA specific qPCR assay. Sci Rep. 2015; 5: 11590. [CrossRef]

21. Munafo DB, Robb GB. Optimization of enzymatic reaction conditions for generating representative pools of cDNA from small RNA. RNA. 2010; 16(12): 2537-52. [CrossRef] 
22. Raymond CK, Roberts BS, Garrett-Engele P, Lim LP, Johnson JM. Simple, quantitative primer-extension PCR assay for direct monitoring of microRNAs and short-interfering RNAs. RNA. 2005; 11(11): 1737-44. [CrossRef]

23. Sharbati-Tehrani S, Kutz-Lohroff B, Bergbauer R, Scholven J, Einspanier R. miR-Q: a novel quantitative RT-PCR approach for the expression profiling of small RNA molecules such as miRNAs in a complex sample. BMC Mol Biol. 2008; 9:34. [CrossRef]

24. Benes V, Castoldi M. Expression profiling of microRNA using real-time quantitative PCR, how to use it and what is available. Methods. 2010; 50(4): 244-9. [CrossRef]
25. Rai P, Kumar BK, Deekshit VK, Karunasagar I, Karunasagar I. Detection technologies and recent developments in the diagnosis of COVID-19 infection. Appl Microbiol Biotechnol. 2021; 105(2): 44155. [CrossRef]

26. Wang J, Cai K, Zhang R, He X, Shen X, Liu J, et al. Novel One-Step Single-Tube Nested Quantitative Real-Time PCR Assay for Highly Sensitive Detection of SARS-CoV-2. Anal Chem. 2020; 92(13): 9399-404. [CrossRef] 